\title{
Elimination of the negative effect of Fe-rich intermetallic phases in secondary (recycled) aluminium cast alloy
}

Lenka Hurtalová, Eva Tillová

University of Žilina, Faculty of Mechanical Engineering, Department of Materials Engineering, Univerzitná 8215/1, 01026 Žilina, Slovak Republic. lenka.hurtalova@fstroj.uniza.sk; eva.tillova@fstroj.uniza.sk

Improved mechanical properties of secondary alloys are strongly dependent upon the morphologies, type and distribution of the second phases, which are in turn a function of alloy composition and cooling rate. In Al-Si-Cu type alloys, however, Fe showed to have the most detrimental effect on ductility of all of the common impurities. Iron impurities can either come from the original bauxite ore or be acquired during subsequent melting, remelting and casting, e.g. by contamination from the melting pot etc. The shape of iron compounds is more influential than the quantity of those iron compounds. Therefore was used heat treatment of experimental material that consisted of solution treatment for $2,4,8,16$ or 32 hours at temperatures 515 and $525^{\circ} \mathrm{C}$; water quenching at $40{ }^{\circ} \mathrm{C}$ and natural aging for 24 hours at room temperature. In that smaller cooling rate setting causes granular structure and lower values of mechanical properties by casting into the sand moulds (sand casting) and higher cooling rate setting causes fine-grained structure and higher values of mechanical properties by casting into the metallic moulds (chill casting), were used AISi9Cu3 cast alloy cast in to the sand and the metallic moulds.

Keywords: sand casting, chill casting, secondary aluminium alloys, heat treatment, Fe-rich phases

\section{Acknowledgement}

This work has been supported by Scientific Grant Agency of Ministry of Education of Slovak republic and Slovak Academy of Sciences, $N^{o} 1 / 0841 / 11, N^{o} 1 / 0460 / 11$ and the Project EU: The competence Centrum for industrial research and development in the field of light metals and composites - ITMS: 26220220154.

\section{References}

[1] CERRI, E., EVANGELISTA, E. (1999). Metallography of aluminium alloys. Training in aluminium Application Technologies, 1202, pp. 2-20.

[2] SEIFEDDINE, S. (2007). The influence of Iron on the microstructure and mechanical properties of cast Al-Si alloys, Literature review, Vilmer project - 5.2 casting, Sweden.

[3] BLAŠČÍK F. et al. (1988). Technológia tvárnenia, zlievarenstva a zvárania. Bratislava (in Slovak)

[4] MAE, H. et al. (2008). Comparison of ductile fracture properties of aluminium casting: Sand mold vs. metal mold. International Journal of Solids and Structures, Vol. 45, pp. 1430-1444.

[5] NADELLA, R., ESKIN, G. D., DU, Q., KATGERMAN, L. (2008). Macrosegregation in direct-chill casting of aluminium alloys. Progress in Materials Science, Vol. 53, pp. 421-480.

[6] TILlovÁ, E., CHALUPOVÁ, M., HURTAlOVÁ, L. (2011). Evolution of phases in a recycled Al-Si cast alloy during solution treatment. The Scaning Electron Microscope. INTECH, pp. 411-438.

[7] TAYLOR, J. A. (2004). The effect of iron in Al-Si casting alloys, 35th Australian Foundry Institute National Conference, Adelaide, South Australia, pp. 148-157.

[8] TILLOVÁ, E. et al. (2011). Quality control of microstructure in recycled Al-Si alloy. Journal for science, research and production, Manufacturing Technology, Vol. 11, No. 11, pp. 70-76.

[9] ĎURINÍKOVÁ, E., TILLOVÁ, E. (2011). Phase and structure characteristics of recycled AlZn10Si8Mg cast alloy. Journal for science, research and production, Manufacturing Technology, Vol. 11, No. 11, pp. 70-76.

[10] HURTALOVÁ, L. et al. (2012). Changes in structural characteristics of hypoeutectic al-Si cast alloy after age hardening. Materials science (Medžiagotyra), Vol. 18, No. 3, pp. 228- 233.

[11] HURTALOVÁ, L. et al. (2012). Effect of chemical composition of secondary Al-Si cast alloy on intermetallic phases. MTM - Machines technologies materials, International virtual journal, Issue 9, Y. 6, pp. 11-14.

[12] WEISS, V. (2011). Influence of the casting mould on surface and structure duality of the AlZn5.5Mg2.5Cu1.5 alloy. Slévarenství, Foundry Industry Journal, Vol. 7-8, pp. 216-218.

[13] SAMUEL, A. M., SAMUEL, F. H., DOTY, H. W. (1996). Observations on the formation of $\beta$-Al5FeSi phase in 
319 type Al-Si alloys. Journal of Materials Science, Vol. 31, pp. 5529-5539

[14] MA Z. et al. (2008). A study of tensile properties in Al-Si-Cu and Al-Si-Mg alloys: Effect of $\beta$-iron intermetallics and porosity. Materials Science and Engineering, A 490, pp. 36-51

[15] SEIFEDDINE, S., JOHANSSON, S., SVENSSON, I. (2008). The influence of cooling rate and manganese content on the $\beta-\mathrm{Al}_{5} \mathrm{FeSi}$ phase formation and mechanical properties of Al-Si based alloys. Materials Science and Engineering, A 490, pp. 385-390.

[16] KIM, H. Y. et al. (2006). Effects of Mn on the crystal structure of $\alpha-\mathrm{Al}(\mathrm{Mn}, \mathrm{Fe}) \mathrm{Si}$ particles in A356 alloys. Journal of Crystal Growth, Vol. 291, pp. 207-211.

[17] MOUSTAFA, M. A. et al. (2003). Effect of solution heat treatment and additives on the microstructure of Al-Si (A413.1) automotive alloys. Journal of Materials Science, Vol. 38, pp. 4507-4522. 